\title{
AUSCHWITZ E OS DESAFIOS DA REPRESENTAÇÃO
}

Fernanda Müller

Doutoranda em Literatura - UFSC

Resumo: A partir dos conceitos de representação e de catástrofe, proponho uma reflexão acerca de duas obras dedicadas a um evento que, devido a sua própria natureza, não previa testemunho, diálogo ou resposta: o extermínio nazista. De autoria de Primo Levi, a primeira obra analisada vem da literatura, é o livro É isto um homem? (Se questo è un uomo?), destacado pela crítica por oferecer "um tipo de testemunho perfeito". A segunda delas, extraída do cinema, é a película Noite e neblina (Nuit et brouillard), dirigida por Alain Resnais. Fugindo do estilo lacrimogêneo das grandes produções hollywoodianas, o filme traça um paralelo cortante entre o presente e o passado: a beleza e o horror, a tranqüilidade e o caos, a poesia e a dor, o esquecimento e a lembrança. Somadas, essas duas obras evidenciam a importância de conferir novos significados aos restos, os problemas da representação da catástrofe e o extermínio da história perante a virtualidade de nosso tempo.

Palavras-chave: Representação; Catástrofe; Shoah.

Abstract: Departing from the concepts of representation and catastrophe, I propose a reflection about two works dedicated to an event which, on account of its own nature, do not forecast testimonial, dialogue or answer: the Nazism Extermination. By Primo Levi, the first work analyzed comes from literature, it is the book Is this a man? [Se questo è un uomo?], stand out by criticism to offer "a kind of perfect testimonial". The second one, extracted of cinema, is the film Night and fog [Nuit et brouillard]. Directed by Alain Resnais, it detaches from the typical soppy style of Hollywood's great productions, to set up a paralleled cutting between present and past: the beauty and the horror, the peace and the chaos, the poetry and the pain, the forgetful and the remembering. Amount, the both works evidence the importance of giving new meanings to the rests, the problems of catastrophe representation and the history extermination in the presence of our virtually times.

Keywords: Representation; Catastrophe; Shoah. 


\section{Entre restos}

Recorrendo à etimologia da palavra catástrofe, encontramos uma sucessão de significados. Derivada da forma grega Katastrophé, e depois do latim tardio catastrophe, designa uma virada para baixo, ruína, desabamento ou desenlace dramático. Todavia, é sua expressão hebraica, Shoah, que melhor exprime o campo junto ao qual esse texto se inscreve, uma vez que "Holocausto", terminologia que muitos ainda insistem em adotar, diz respeito a uma imolação, um sacrifício ou uma penitência, o que definitivamente não foi o caso. Os campos equivaleram, isso sim, à aniquilação moral e ao assassinato de pessoas, nas palavras do próprio Hitler, "mortos como piolhos", como pragas sociais.

Criadores do primeiro Estado radicalmente biopolítico ${ }^{1}$, os nazistas retiraram no âmbito político toda a humanidade dos detentos antes de enviá-los aos campos de concentração. Reduzidos legalmente a corpos viventes, os presos passaram a ser tratados, na expressão de Hannah Arendt, como "futuros cadáveres". Legitimando a exclusão desses homens e mulheres de qualquer direito, o Estado poderia matá-los sem incorrer em crime algum. Eliminando não apenas judeus, mas toda a vida considerada indigna de ser vivida pelos padrões supostamente científicos de então - sejam eles deficientes mentais ou físicos, inimigos políticos e em alguns casos até mesmo oficiais desertores ou soldados mutilados em campo -, a biopolítica que tem início aí transformou-se em tanatopolítica, quer seja, política da morte, e o campo de concentração tornou-se seu paradigma contemporâneo. A questão fulcral, enfatizada por Giorgio Agamben, deixa de ser como esses crimes hediondos puderam ser cometidos, para ser uma tentativa de evidenciar quais dispositivos permitiram que seres humanos fossem privados de todos os seus direitos e prerrogativas a ponto de serem reduzidos a uma animalidade matável, equiparados a insetos (AGAMBEN, 2004). Ao lado desses dispositivos - científicos, jurídicos e políticos -, destaco os de ordem estética. Afinal, como postula a polêmica tese do mito nazista, da obscura ideologia do nazismo à realidade infernal dos campos de extermínio, encontrava-se também uma grave crise de representação (NANCY; LABARTHE, 2002).

Se o projeto do nazismo passava pela criação de um mito germânico, fazendo uso de variados suportes representativos, o deste texto é o oposto. Trata-se de resgatar representações feitas por quem não sucumbiu calado para sempre, esboçando uma tentativa de representar o impossível. Afinal, depois de décadas de homenagens póstumas e superproduções cinematográficas tratando da Segunda Guerra Mundial, o que sabemos sobre os campos de concentração? Que representações chegaram até nós? O que nos dizem? O que resta? Agamben afirma que não é possível destruir integralmente o humano. Sempre resta algo: o testemunho. Para além da ignorância, do folclore e do estereótipo que não pergunta o porquê, nem consegue observar como novas formas de política, aliás, de biopolítica, ameaçam se instaurar, proponho uma reflexão. Se o irrepresentável existe, como afirma Jean-François Lyotard, seria esse o caso dos campos de concentração, diante dos quais a compreensão é por vezes paralisada pelo horror e pela dor? Analisando duas obras "pós-Auschwitz", uma extraída da literatura e outra do cinema, tentarei esboçar uma resposta.

\section{Entre espelhos e cachimbos}

Oriunda do latim, a palavra representatione designava o ato de expor, trazer à luz, reproduzir ou re-apresentar. Todavia, não se esgotando nesses termos, sua significação vem sendo incessantemente discutida no âmbito acadêmico, seja no das artes, do direito ou da filosofia, seja no da política, da psicologia ou da semiótica. Observando algumas de suas acepções, "representar" tem sido utilizado no sentido de substituir um elemento por outro em uma equação, desempenhar um papel em um espetáculo teatral ou assumir uma posição legal de modo a atuar em nome de alguém em um tribunal. Igualmente se refere à delegação de 
poderes conferidos pelo povo a certas pessoas, a fim de que exerçam em nome dele as funções próprias dos órgãos eletivos da administração pública. Designa ainda a celebração de um contrato entre pares de modo a uma parte promover a outra, efetuando negócios em nome dela ou aproximando clientes, além de nomear o conteúdo concreto apreendido pelos sentidos, pela imaginação, pela memória ou pelo pensamento. Ora, poderíamos dizer, em síntese, que representar está associado tanto a interpretar, ocupar o lugar de alguém, desempenhar por outrem, quanto a relembrar, trazer de volta à cena.

Mesmo restringindo a representação ao âmbito filosófico e literário, o termo permanece nebuloso. Rememorando a Grécia Antiga, merecem atenção as discussões em que se tratava da natureza da representação. Platão considerava toda criação uma imitação, inclusive a criação divina, que apenas simulava o mundo das idéias, tal qual espelho, imagem duplicada, falsificada. A representação artística, por conseguinte, era vista pelo filósofo como uma cópia do mundo já copiado por Deus, ou seja, uma imitação de segunda mão. Aristóteles, no entanto, rejeitou essa noção de mundo das idéias e considerava o drama como "a imitação de uma ação". Conforme explícito em sua Poética, a arte merece o status de representação do mundo negado por Platão. Assim, no modo de ver aristotélico, mimesis é o equivalente à representação.

Pedra de toque por séculos, esse conceito foi repensado modernamente por estudiosos como Erich Auerbach, que esboçou princípios de reconhecimento a partir de obras singulares, porquanto representativas, nos ensaios do volume Mimesis: a representação da realidade na literatura ocidental (1946). Fazendo uso de textos de escritores como Homero, Dante, Rabelais, Schiller, Stendhal ou Virgínia Woolf, sua noção de representação passou a definir um cânone restrito e cerceado a uma tradição humanista, eurocêntrica e estruturalista. Diante do quadro instaurado, o primeiro passo foi dado por pensadores e artistas modernos, como Antonio Gramsci e Walter Benjamin - ambos, aliás, vítimas do fascismo e do nazismo -, sendo aprofundando por diversas correntes, entre as quais os Estudos Culturais, que buscaram dilatar os limites do que se tomava por representação. Colocando em pauta questões de identidade, teóricos da nova corrente passaram a evocar a contemplação de outros textos que também seriam representativos, conclamando não os clássicos apontados por Auerbach, mas aquela produção cultural que estava posta à margem, esquecida ou relegada, mas que, fundida sobretudo às idéias de testemunho e de memória recuperada, permitiriam a presença do diferente, do excluído, até então sem voz.

Sem impor um conceito fechado, sob pena de passarmos de um extremo a outro, mas tentando dilatar seus limites através da adição, precisamos ter em mente que o que está em jogo na representação não é a coincidência com o real, campo minado. Não devemos confundir representação com verdade, mas com uma busca da mimesis, em maior ou menor grau, em que se alcança a imitação, a representação do real através da arte, ou seja, a recriação da realidade através da imitação. Se tudo aquilo que é contado depende de uma forma, de escolhas objetivas e subjetivas, representar alguma coisa "real" é trazê-la a tona de um modo particular, constituindo uma representação singular, não um objeto ou fato tal qual foi, mas tal qual poderia ter sido. Cabe aqui relembrar a polêmica gerada outrora em torno das telas de René Magritte que representou a traição das imagens na forma de um cachimbo acompanhado dos dizeres: “Ceci n'est pas une pipe". Diante da má interpretação da composição, o próprio pintor se viu obrigado a reiterar posteriormente, em tela similar: "Ceci continue de ne pas étre une pipe", reafirmando assim que signo e objeto não coincidem e, portanto, não devem ser confundidos: possuem existência autônoma, ainda que uma obra sugira por vezes o contrário.

\section{Tragédias na escrita}

Conforme tentei explicitar, o reconhecimento do valor representativo de uma obra está ligado a uma série de conceitos e interpretações, entre os quais a forma tomada pela 
reconstrução da realidade na ficção. Fazer essa passagem, em todo caso, não é uma tarefa simples, principalmente quando se trata de compor um texto pautado num evento ocorrido. $\mathrm{O}$ escritor percebe logo que imparcialidade e precisão, no sentido de equivalência ao original, não constituem opções disponíveis. Formar significados implica traí-los no momento da narração, bem como esquecer mostra-se mais natural do que lembrar. Ora, se o real é um momento efêmero, impossível de ser retido, o caminho para se chegar até a realidade deve passar pela irrealidade, estrada tortuosa, cujos obstáculos resultam da intensidade do vivido, sobretudo perante situações traumáticas.

Aproximando-se do desvio, da tragédia e da catástrofe, Artur Nestrovski e Márcio Seligmann-Silva revelam a duplicidade oculta nesses termos, uma vez que a representação depende de uma catástrofe (sem a qual não há o que representar), mas a catástrofe igualmente dificulta, ou mesmo impede a representação (NESTROVSKI; SELIGMANN-SILVA, 2000, p. 7). Questão central e atual da literatura, da arte e das disciplinas humanas em geral, observa-se que as experiências traumáticas decorrentes de catástrofes deixam marcas, mas o acesso a elas nem sempre é possível.

Remetendo-nos novamente aos significados da palavra trauma, notamos sua relação com os termos "friccionar", "triturar" e "suplantar", mas também o sentido de "passar através", superando ou recalcando, registrando ou ignorando o vivido. Abordado por Sigmund Freud em diversas oportunidades, o trauma seria uma experiência intensa demais para ser assimilada pela mente num período curto demais. $\mathrm{O}$ indivíduo não sabe que lembra, mas manifesta em atos obsessivos sem ligação consciente com a atualidade a lembrança latente (FREUD, 1980). O resultado é que, quando há narração, a temporalidade do evento é flutuante, combinando aleatoriamente o presente e os pretéritos de modo desordenado, o que desafia o escritor a não trair a natureza do vivido e o leitor a não desistir do conhecimento. $\mathrm{O}$ que se sabe e o que se desconhece se confundem, tanto para quem experimentou quanto para quem ouve o relato, uma vez que a consciência da catástrofe modifica não só o modo de perceber e de representar, mas também o de se contrapor ao mundo.

Se memória, ensaio e ficção possuem fronteiras arbitrárias que omitimos em favor do termo "representação", cabe enfatizar que são formas que dialogam com o mundo através de particularidades. A fim de contar, o relato deve retornar e passar pelo trauma, pelo indivíduo; se não, vira resto descartável, capítulo empoeirado, lixo televisivo, jornal de ontem. Como assevera Roland Barthes, o real não é um dado e sim uma experiência de cultura que precisa ser reativada, dependendo, para tanto, do indivíduo. Não de um ente coletivo, mas de um ser com personalidade, perspectivas e trajetória particulares, que, ao refazer seu próprio caminho, poderá elucidar aquele seguido pelos demais.

\section{Excesso e exceção}

A violência é um comportamento que perpassa a história humana, como afirma o último texto escrito por Walter Benjamin, nomeado Sobre o conceito de história. Elaborando uma crítica à noção de progresso, o filósofo alemão defende que "nunca existiu um documento da cultura que não fosse ao mesmo tempo [documento] da barbárie" (BENJAMIN, 2000, p. 225). Aponta assim para o fato de a cultura ser, a partir de meados do século $\mathrm{XX}$, toda ela como que transformada em um documento e, mais ainda, servir de testemunho da barbárie. Em detrimento da complexidade do tema, representações violentas são facilmente encontradas. Estamos até saturados delas, sendo obrigados a conviver com o excesso como se este fosse o único instrumento de sensibilização disponível. Se por um lado a selvageria choca, por outro, sua ênfase é responsável por nos anestesiar, na medida em que explora o tema à exaustão. Habituamo-nos e conformamo-nos à sua "fatalidade". Nosso consciente, que, como já assegurava Freud, tem a função de nos proteger dos estímulos, pode ser visto como um dos responsáveis por essa passividade, visto que a maior ameaça que se 
pode receber vem na forma de choques, como o são a vivência ou a narração de cenas dolorosas. Assim, quanto mais corrente se tornar o registro desses choques no consciente, tanto menos se deverá esperar deles um efeito traumático (FREUD, 1980).

Jean Baudrillard exemplifica bem esse mecanismo enfatizando o número infinito de imagens que captamos diariamente, o que, pouco a pouco, faz com que elas não sejam mais capazes de produzir choques e não nos comuniquem mais coisa alguma. Afirma o crítico:

\begin{abstract}
a miséria e a violência nos tocam ainda menos porque elas nos são significadas e mostradas abertamente. É a lei do imaginário. É preciso que a imagem nos toque por ela mesma, que ela nos imponha sua ilusão específica, sua língua original, para que algum conteúdo nos afete. Para que haja transferência afetiva sobre o real, é preciso haver contratransferência da imagem a estar concluída. Lamenta-se que o real tenha desaparecido sob o pretexto de que tudo passa pela imagem (BAUDRILLARD, 2002, p. 148).
\end{abstract}

Tentando fugir de construções vazias e banais, infelizes na tarefa de comunicar, selecionei as representações para este trabalho. Levando em conta a fala do poeta Paul Celan, para quem ninguém testemunha pelas testemunhas, resolvi começar pelo relato daqueles que não sucumbiram. Devido à natureza breve desse texto, todavia, meu olhar junto à literatura recai unicamente sobre o volume É isto um homem? (Se questo è un uomo?), de autoria de Primo Levi, o qual oferece, nas palavras de Agamben, "um tipo de testemunho perfeito", uma vez que, quando volta para casa, entre os homens, relata sem cessar a todos o que viveu (AGAMBEN, 2000). Passando da arte da escrita para a da imagem em movimento, meu recorte junto ao cinema objetivou fugir das grandes produções de Hollywood, em favor de uma que tenta explorar o tema dos campos de concentração com profundidade. Trata-se do quase anônimo ao público de hoje Noite e neblina (Nuit et brouillard), de Alain Resnais.

\title{
Daqui, só pela chaminé
}

A idéia de um senhor que se suicida aos 70 anos gozando de boa saúde gera no mínimo estranhamento. Sobretudo se descobrimos que ele foi um dos três únicos sobreviventes de Auschwitz de um grupo de 650 italianos para lá enviados. Contrariamente ao que se possa imaginar, o índice de suicídio nos campos de concentração era relativamente baixo. Apesar de a morte ser contemplada no abraço voluntário à cerca elétrica, idéia confortadora perante a falta de alternativas, raramente tal ato era levado a cabo. Primo Levi justifica a defesa da condição miserável como resultado da humanidade que o ato de retirar a própria vida demanda. Tendo essa condição reduzida a um grau zero, ou a algo bem próximo disso, atentos apenas às necessidades mais elementares, pouco tempo restava para refletir e tomar uma decisão como essa. Era apenas ao saírem dos campos, aos raros que conseguiram, que a situação trágica se afigurava. Sem bens, sem lar, sem família, para muitos parecia não haver mais sentido em continuar a viver: "quem perde tudo, muitas vezes perde também a si mesmo" (LEVI, 1988, p. 25). Foi nesse momento, diante da falta de perspectivas, que muitos retiraram a própria vida, gozando ao menos do benefício de serem seus próprios algozes.

Esse não foi o caso do homem em questão. Primo Levi (1919-1989) chegou a Auschwitz em 1944, de onde saiu apenas ao final da Guerra. A partir daí sua vida foi a tentativa de propagar uma história. Não apenas a daqueles que sobreviveram, mas a dos milhões que se foram. Sem voz. Sobreviver, entretanto, não significa apagar as marcas profundas deixadas pelo nazismo, mas aprender a conviver com elas, como registrou em sua obra. Diante dos anos vindouros e das páginas em branco, que atitude tomar? Químico por formação, guerrilheiro por ideologia, sobrevivente por acaso, ao jovem de 24-25 anos coube refazer-se humano para vir a se tornar escritor, ou, ao contrário, incorporar o narrador para a 
partir daí tentar compreender a própria condição. É isto um homem? (1988), escrito entre 1945 e 1947, ou seja, ainda no calor da hora, revela parte dessa trajetória.

Não é fácil abordar essa obra cuja leitura exige tanto de nós. Abrindo o texto, um poema homônimo ao livro adianta em linhas ásperas e cortantes o teor do relato a seguir, repetindo a pergunta que perpassa toda a obra: é isto um homem?, é isto uma mulher? (LEVI, 1988, p. 9). Adentrando o texto, surge outra indagação: quem narra a história? Autor e narrador fazem questão de confundir-se desde o primeiro momento, conforme evidencia o prefácio no qual se lê "acho desnecessário acrescentar que nenhum dos episódios foi fruto de imaginação" (ibid., p. 8).

Buscando delinear uma história coletiva, um destino vivido aos milhares, mas sentido individualmente, a figura que assume a narração está consciente de servir como ponto de partida para compreender a trajetória dos demais. São incontáveis narrativas que compartilham um único enredo: ao chegar ao campo, já despojado dos bens e separado da família, era preciso abrir mão até dos pertences mais pessoais, como uma foto ou um lenço. Aparentemente um ato singelo, mas carregado de doloroso simbolismo. A imagem, moldada pelos longos cabelos femininos, ou delineada pela barba e bigode entre os homens, sofre a primeira adulteração, ao serem tosquiados como bichos, sem cerimônia alguma. A intimidade da nudez é exposta aos olhares assustados dos demais. É só o começo da rápida metamorfose do corpo que seria surrado, emagreceria e envelheceria em poucas semanas, vítima da fome, do frio e dos maus tratos. Marcando essa passagem, o nome próprio cede lugar a um número, gravado na mente, na carne e na alma. Morte em vida, a nova fase separa dois seres distintos: Levi, o homem italiano transforma-se na personagem de uma vida passada, uma reencarnação distante no tempo e no espaço, dando lugar a uma nova identidade, ou melhor, a ausência de uma identidade reconhecivelmente humana, em prol da impessoalidade desumana do número 174.517. Em conflito com a representação que outros criaram para si, o passado é rechaçado pelo presente. A imagem de uma pessoa deixa de condizer com a que carregava em sua memória, passando a ser vista no cinzento rosto indistinguível dos demais farrapos listrados, reflexo da própria condição.

O autor-narrador flutua na interpretação dessas duas entidades. Uma delas é Levi, aquele que se negou a gravar, a exemplo dos demais, seu número no fundo da gamela da sopa, optando por registrar nesse espaço o nome próprio. A outra é aquele que se auto-referencia ao longo do relato através desse mesmo número negado, como no trecho: "Eu, Häftting 174.517, estou de pé em seu escritório, que é realmente um escritório reluzente, limpo, bem arrumado; tenho a sensação de que, se tocasse em qualquer coisa, deixaria uma marca de sujeira." (LEVI, 1988, p. 107). A relação estabelecida com a nova designação é ambígua, atitude muito comum entre os sobreviventes, como aponta Célia Ramos em seu estudo sobre as tatuagens nazistas (2006). De acordo com a pesquisadora, o número tatuado representava uma matrícula na sociedade dos excluídos, signo de controle político dos segregados da cultura dominante, mas também passaria, nos anos subseqüentes à vivência nos campos, a comunicar, a simbolizar um documento político, autenticidade da deportação, parte integrante de quem o sujeito veio a tornar-se. Essa constatação é evidenciada no texto, na afirmação: "ninguém deve sair daqui, poderia levar ao mundo, junto com a marca gravada na carne, a má nova daquilo que, em Auschwitz, o homem chegou a fazer do homem" (ibid., p. 55).

Ao lado do narrador-protagonista, surgem as demais personagens, vítimas e carrascos. Tentando aproximá-los de quem lê, é lançada luz sobre a condição daqueles que se tornaram, por decreto, exilados da vida. São famílias inteiras que, às vésperas da viagem derradeira, dão banho em suas crianças e lavam suas roupinhas, rezam, choram, entoam cantos ou guardam silêncio. E desse modo, pouco a pouco, ganham nome, profissão e características capazes de humanizá-las em meio à massa disforme dos trens e aos dez mil rostos amontoados e constantemente renovados no campo. Vemos Renzo ser espancado ao 
tentar despedir-se da noiva Francesca, ou a menina Emília, de três anos, curiosa, ambiciosa, alegre e inteligente ser condenada à morte. Somos apresentados ao colega de enfermaria Walter Bonn, holandês educado e de certa cultura, ao amigo Alberto, italiano de vinte e dois anos, adaptável, esperto, inteligente e companheiro; e ao vienense, Sigi, o comilão saudoso de casa e dos cuidados da mãe. Há espaço ainda para os franceses simpáticos que igualmente convalesciam de escarlatina, o camponês Arthur e o professor Charles, sobreviventes nos dias finais de desmantelamento do campo, entre dezenas de outros. Não meramente corpos, mas pessoas com trajetórias particulares fora e dentro do campo, com sonhos e pesadelos, fé, descrença ou esperança. São nomes que os livros de história omitem, substituindo por elevados algarismos, sem levar em conta que sua multiplicação na ordem simbólica sempre equivale a uma subtração. Isso quer dizer, como apontado por Baudrillard, que a morte de um homem é um acontecimento considerável, mas com a morte de mil indivíduos, a morte de cada um é mil vezes menos importante (BAUDRILLARD, 2006, p. 156). Para evitar que a multiplicação dos números faça com que seu valor seja reduzido a zero, anulando seu impacto, Levi faz questão de registrar a presença e a ausência individual, redescobrindo assim o valor insubstituível de cada ser. Humano, único, indivisível, insubstituível. Num ponto intermediário entre as vítimas e os carrascos, algo além do bem e do mal, está a nomeada zona cinzenta. Agamben enfatiza a importância da descoberta inédita de Levi, referente a uma matéria que resulta refratária a qualquer tentativa de determinar a responsabilidade, equivalendo a um novo elemento ético: o dos detentos que tentando aumentar suas chances de sobrevivência trabalharam para o nazismo. Nesse lócus se rompe a cadeia que une os dois extremos, e o oprimido se faz opressor.

Finalmente, em oposição geral aos detentos é traçado o perfil dos agressores e executores que, em processo semelhante, recebem nome, profissão, temperamento e rosto. Entre eles estão as faceiras e falantes moças do laboratório que comiam pão com geléia na frente de famintos, rechaçando-os pelo seu "fedor de judeu", ou o inocente e bruto Alex que limpou a mão preta de graxa pegajosa na roupa de Levi, sem ódio, escárnio ou respeito. A soma desses perfis singulares, todavia, culmina na composição de um grande inimigo, antagonista maior na trama, vilão na vida: a personagem de fundo coletivo "povo alemão". "Destruir o homem é difícil, quase tanto como criá-lo: custou, levou tempo, mas vocês alemães, conseguiram" (LEVI, 1988, p. 152), dirige-se Levi ao leitor, bem como o faz ao final da representação, quando jaziam em vida entre mortos e fantasmas, e é evocado novamente o grande culpado, cuja "obra de embrutecimento apreendida pelos alemães triunfantes tinha sido levada ao seu término pelos alemães derrotados" (ibid., p. 173).

Frente ao evento, o narrador recusa o papel de juiz, exigindo o direito das vítimas de falar como "sobreviventes" e não apenas como "testemunhas". Afinal, sobreviventes são os que restaram; já o papel de testemunha exigiria muito mais do observador, uma lucidez até impossível, como enfatiza: "hoje - neste hoje verdadeiro, enquanto estou sentado frente a uma mesa, escrevendo - hoje, eu mesmo não estou certo de que esses fatos tenham realmente acontecido." (ibid., p. 105). Essa incerteza, que aparentemente não coincide com o objetivo maior de conferir autenticidade ao relato, acaba por fortalecê-lo, criando uma relação de sinceridade entre as partes, conscientes de que a aporia de Auschwitz está na não-coincidência entre fatos e verdade, entre comprovação e compreensão (AGAMBEN, 2000, p. 9). É interessante pensar, em todo caso, que, mesmo chegando a duvidar do que aconteceu, uma vez que os fatos extrapolam o crível, Levi não os esquece, afirmando conservar uma memória visual e auditiva das experiências que nem ele era capaz de explicar. São frases em línguas desconhecidas que perambulariam em sua memória, tal qual uma preparação inconsciente para testemunhar, como declarou em entrevistas posteriores.

O objetivo claramente expresso na narrativa era o de fornecer documentos para um estudo de certos aspectos da alma humana, como a incerteza perante o incompreensível. Para 
tanto, a estrutura do campo foi dissecada em seus detalhes e pormenores em capítulos curtos, na forma de pequenos ensaios. Não escaparam as categorias de classificação dos condenados, a macabra ciência dos números que revelavam a procedência e a permanência no campo; a geografia de arame farpado, barracões e galpões; a moral flutuante do lugar e mesmo a indústria e o comércio de artigos de uso pessoal e de informações, verdadeira bolsa de valores entre detentos. Igualmente, os rituais de arrumação das camas, de contagem e de limpeza, o trabalho extenuante e as necessidades fundamentais do corpo capazes de calar a voz do espírito recebem abordagem própria. A crueza das regras do lugar, claras ou tácitas, é escancarada, sobretudo, através dos provérbios e máximas do campo, como as terríveis: "nunca pergunte"; "os privilegiados oprimem os não-privilegiados"; "come teu pão e, se puderes, o do vizinho"; "vocês não estão mais em casa"; "isto não é um sanatório"; "daqui só se sai pela chaminé". Tais sínteses nos conduzem à linguagem do campo, babel e algaravia, com gírias e imaginário próprios. A palavra "nunca", por exemplo, no linguajar interno era expressa por "amanhã de manhã", "inverno" significava "ainda mais", enquanto ser um "muçulmano" equivalia a estar irrevogavelmente condenado à morte. Esta noção de condenação prévia, aliás, merece um olhar mais atento.

O muçulmano era o ser eliminado duas vezes de dentro do campo, rejeitado por todos, cada qual a sua maneira. A primeira delas era a exclusão entre os demais detentos que reconheciam sua incapacidade de adaptação e permanência, afastando-se como forma de se proteger do futuro que aguardava aquele indivíduo. A segunda exclusão era a derradeira, a dos oficiais que reconheciam essa inaptidão e o assassinavam. Expulso da sociedade dos condenados e banido da vida, o muçulmano passa a demarcar não apenas um limite entre a vida e a morte, como aponta Agamben, mas também o umbral entre o homem e o nãohomem. Lacuna silenciosa, o teórico tenta lhe dar voz. Tomando conhecimento de uma monografia que continha um capítulo intitulado "Eu era um muçulmano", encerra O que resta de Auschwitz oferecendo as páginas finais à reprodução desses relatos. Para Shoshana Felman, contudo, a Shoah é um acontecimento sem testemunho, no duplo sentido de que sobre ela é impossível testemunhar, tanto do seu interior - porque não se pode falar de dentro da morte - quando de seu exterior - porque quem está fora está excluído por definição do acontecimento. Assim, se muçulmano era o condenado cuja apatia generalizada eliminava suas chances de sobrevida, como apontado por Levi, a condição de sobrevivente exclui seu relato. Intestemunhável, permanece como a abstração do relato porque é aquele que não voltou de dentro da câmara de gás para contar o que viveu.

Diante do absurdo relatado pelos sobreviventes dos campos, muitos permaneceram estáticos, numa atitude de incredulidade. Tanto as vítimas quanto os opressores estavam conscientes da impossibilidade de sua história, do nonsense ocorrido nos Lager. Levi (2004, p. 14) afirma que, numa distância de anos, "hoje se pode bem afirmar que a história dos Lager foi escrita quase exclusivamente por aqueles que, como eu próprio, não tatearam seu fundo. Quem o fez não voltou, ou então sua capacidade de observação ficou paralisada pelo sofrimento e pela incompreensão". É nesse grande paradoxo que se estabelece a obra, não só a de Levi, mas a de outros sobreviventes. A grande metáfora do campo enfocada pelo escritor italiano e retomada posteriormente em um conjunto de ensaios e reflexões elaborados na maturidade é a dos "afogados e sobreviventes". Afogamento remete à água, simbolicamente uma mistura ambivalente de nascimento e de morte. Quase todos afundaram, poucos conseguiram manter-se na superfície. Todavia, o que os tragava não é bem representado pela pureza do elemento cristalino, e sim, como fica explícito com a leitura do texto, por um caldo lodoso, soma de água salobra, neve suja, excrementos, pancadas e humilhações.

Motivado pela impensável mas não menos tangível culpa de ter sobrevivido, Levi se esforçou para compor seus relatos. Locus classicus da literatura sobre o campo, essa inquietação advém da sensação de estar ocupando o lugar que poderia ser de outro. Mais 
ainda, segundo o autor, quem se salvou não foram os melhores, mas os piores. Os que se aliaram à SS, os que traíram seus companheiros de infortúnio e os que se adaptaram a obedecer, a comer menos, a sentir frio, a passar sede, a negociar o pouco que tinham. Sem se apiedar do seu destino ou tentar se vingar, o desejo de melhor compreender a própria experiência parece ter sido o propulsor de Levi nos nove relatos que compôs, entre ensaios, poemas e romances. Chamar a atenção para uma tragédia que só acabou em parte, pois continua a nos espreitar: esse é um ponto importante a ser observado. Levi mostra os descaminhos da biopolítica, de modo a evidenciar que o campo de extermínio representa apenas o último elo da corrente. Trata-se de uma engrenagem movida pelo preconceito, pela idéia latente de que "cada estrangeiro é um inimigo", e cuja manifestação na forma de uma lógica rigorosa de assassinato despersonalizado nos ameaçará enquanto subsistir essa concepção.

\section{Extermínio da história}

Muito embora os nazistas tenham explodido as câmaras de gás e os fornos crematórios, as ruínas ainda existem. Embora os documentos tenham sido queimados às pressas durante os últimos dias de guerra, e essa perda seja irremediável, restaram sobreviventes. Além disso, ao perder a guerra, felizmente, o nazismo não teve a seu favor o direito do vencedor de manipular a verdade como lhe conviesse. Contudo, ao invés de o tempo esclarecer a infâmia, colocando a nu o ocorrido, está provocando efeitos historicamente negativos. O próprio Primo Levi chamava atenção para o fato de a maior parte das testemunhas já não estar mais entre nós, de modo que as que restam e concordam em testemunhar já não dispõem mais das mesmas lembranças decorridos mais de 60 anos. Esse problema não é recente. Como forma de se conformar, confortar ou anular o passado, a negação que perdura até hoje já podia ser sentida no decorrer da primeira década da libertação dos campos. Foi em resposta a esse segundo extermínio, o da história, que Alain Resnais filmou Noite e neblina (Nuit et brouillard), sob encomenda do Comitê de História da Segunda Guerra Mundial, para lembrar a libertação dos campos, em 1955.

Produzir essa película não foi tarefa fácil. Resnais hesitou entre dirigi-lo ou não, pois temia ficar associado à imagem de diretor de documentários, quando seu desejo maior era filmar ficção. Além disso, acreditava que "só um realizador que tivesse sido deportado poderia assumir tal projeto", como afirma em longo depoimento reproduzido no livreto que acompanha o DVD. Por esse motivo, sua película só ganhou a forma pela qual a conhecemos ao ser apresentado ao poeta Jean Cayrol, um sobrevivente dos campos de concentração. Cayrol só se convenceria a escrever o texto após ver a montagem inicial das filmagens, compostas com imagens de cinejornais, fotografias e todo tipo de documento que mostrasse os campos de concentração coletados até então por Resnais. Tendo como narrador Michel Bouquet e a trilha sonora do músico Hanns Eisler, delineia-se a equipe que concretizaria o projeto. Além disso, o diretor teve a idéia de viajar para os locais onde funcionaram os principais Lagers, como Auschwitz e Sachsenhausen, e filmá-los em película colorida. O choque das imagens bucólicas, contendo amplos gramados verdes e vastas paisagens com pinheiros sob céu azul, decorre de sua oposição às imagens de horror retiradas dos arquivos, fazendo menção aos mesmos lugares que, uns poucos anos antes, eram cinzentos e letais.

Dispondo das imagens antigas e das cenas recentes, Resnais compõe algo muito diferente dos relatos dos sobreviventes. Não tenta recriar histórias particulares, refilmando episódios, mas dispõe aquilo que vinha sendo relegado por outros, ressignificando os restos. Ao invés de mostrar mulheres tendo seu cabelo tosquiado, mostra montanhas inimagináveis de cabelos e pêlos num galpão. Igualmente impressionam os montes de óculos e os milhares de calçados, muitos dos quais pequenos e frágeis porque infantis, guardados em outro pavilhão. Em vez de cenas de assassinatos, incontáveis ossadas, pilhas de membros e 
cadáveres mutilados, amontoados uns sobre os outros, com olhar de dor ou vazio. Igualmente, as cenas de horror no interior da câmara de gás cederam lugar às imagens das paredes arranhadas pelas unhas dos prisioneiros à beira da morte. Assim, Resnais opera naquilo que poderia se chamar "presença do que está ausente", correspondendo cada um desses elementos metonímicos - unhas, cabelos, ranhuras - ao atestado presencial e residual de quem desapareceu para sempre. Além disso, essas imagens corroboram para evidenciar como nos campos de extermínio não se morria; produziam-se cadáveres. A grande morte que cada qual leva em si, como propôs Rainer Maria Rilke, era substituída por uma matança em série que resultava em cadáveres sem morte, em não-homens. Giorgio Agamben e Hannah Arendt estão entre aqueles que atribuem a essa degradação da morte, muito mais extrema do que a da vida, o ultraje específico de Auschwitz, o nome próprio de seu horror (AGAMBEN, 2000, p. 74). Corpos sendo jogados em grandes valas com tratores chocam mais do que se fossem mostradas imagens de enforcamentos que prevêem um ritual, por menor que seja. Desse modo, a própria imaginação do público atua na reconstrução das lacunas deixadas pelo filme que evoca o horror sem mostrar a ação, mas o seu resultado nefasto: o homem como resto.

De linguagem simples e direta, merece destaque a abordagem ambivalente, que na passagem de imagens transita sem pausas entre o delicado e o brutal, soando como um alerta lancinante contra todo e qualquer tipo de intolerância. A película funciona como uma homenagem aos milhões de vítimas da crueldade nazista, mas suplanta essa intenção de memorial dos desaparecidos em favor de um aviso para aqueles que vêem o regime de Hitler como um momento que pertence ao passado da humanidade. Afinal, o filme faz, paralelamente, uma alegoria à Guerra da Argélia, em curso no momento da filmagem. Em entrevistas posteriores, Resnais confessou essa intenção. Afirmou que sempre pensou em Noite e neblina como uma sutil condenação à decisão francesa de invadir a Argélia. Embora não haja qualquer menção a isso durante a película, a idéia se encaixa perfeitamente no texto delicado e simultaneamente firme de Cayrol. Embora seja um filme sobre a Shoah e, portanto, esteja repleto de imagens da condição inassimilável vivenciada nos campos de concentração, não deseja simplesmente impressionar através da violência. $O$ filme tenta de algum modo superar a imagem cristalizada em nosso imaginário. A idéia principal que percorre as cenas não é simplesmente a do mal absoluto, mas a do mal que permanece à espreita, em qualquer lugar e a qualquer tempo. É preciso estar sempre atento para que ele não destrua as cores do mundo, transformando-o em cinza, preto e branco. Ou em cor de sangue, fuligem e lama.

Apesar de o filme francês ter impressionado quem o assistiu no período posterior ao lançamento, nunca caiu no gosto do grande público. Sua exibição, devido ao fato de ser um curta-metragem de apenas 31 minutos, dificilmente ficou vinculada aos cinemas, o que por si só atrapalhou a difusão das imagens. Além disso, como é comum ao gênero dos documentários, não atraiu o grande público, o que não o impediu, em todo caso, de se consagrar entre os pares como um marco entre os documentários. Por fim, dificultando o alcance, há o tema árido do genocídio, de caráter conhecidamente histórico e não meramente ficcional, o que acaba por afastar o público em definitivo. Aos olhos de Theodor Adorno, o que poderia parecer um desmerecimento seria digno de comemoração. $\mathrm{O}$ filósofo deixa claro, em seu ensaio Crítica cultural e sociedade, a urgência de um pensamento impiedosamente crítico, a necessidade da cultura como instância negativa e utópica, contra sua degradação ao passar pela máquina de entretenimento e de esquecimento. Sem se tornar refém do público, Resnais oferece sua mensagem para quem desejar conhecê-la, sem facilitar o acesso através de simplificações.

O título da produção, Noite e neblina, foi inspirado num livro de Jean Cayrol, Poèmes de la nuit et du brouillard, que por sua vez tirou a expressão do decreto alemão, Nacht und Nebel, que estipulava a deportação das pessoas acusadas de conspirar contra o regime nazista para locais secretos. Mais adequado impossível, visto que remete de maneira 
velada às formas do mundo e às estratégias nazistas a um só tempo. É exatamente nessa combinação de elementos duais que perpassam a seqüência que reside a singularidade maior do filme, estabelecida sobretudo em três pares. O primeiro deles é o contraste entre as imagens do Lager durante a guerra e no pós-guerra: brutalidade e candura. O segundo, a poesia bela e cortante de Jean Cayrol que, aliado ao terceiro, a delicadeza e a melancolia da música de Hanns Eilser, conferem um equilíbrio próprio, capaz de calar fundo. Mais do que uma celebração piedosa das vítimas, o filme tentou impregnar as imagens da rememoração benjaminiana, no sentido de uma memória ativa capaz de transformar o presente. Quer dizer, abandonando o jornalismo às vezes frio e objetivo do documentário, imagem, narração e música combinam-se a fim de compor uma espécie de sinfonia audiovisual que, nas palavras do cineasta francês François Truffaut (apud LABAKI, 2008), "o contrário desses filmes de onde se diz sair melhor do que se entrou". Afirma ainda que nunca se deixa Noite e neblina, uma vez que é uma experiência intelectual, emotiva e estética como poucas propiciadas pelo documentário, em particular, e pelo cinema, em geral.

\section{Da solução à negação final}

Criar através da pureza um mundo mais harmonioso, uma Alemanha mais forte e muito mais bonita. Essa proposta, numa primeira análise mais estética do que política, acarretou uma matança sem precedentes. À frente das estruturas de poder que a comandaram, todavia, não estavam meramente estrategistas bélicos, mas artistas frustrados, crentes no papel do artista-político preconizado por Richard Wagner, que seguiram a cartilha do músico à risca: anti-semitismo, culto ao legado nórdico, mito do sangue puro ("Blut und Boden" "Sangue e solo"), e arte para uma nova civilização. Para a realização desse projeto estético megalomaníaco, entretanto, foi escolhida a destruição como melhor forma de construção ${ }^{2}$. A purificação pelo fogo que destruiu cidades russas, as fogueiras com obras de artes expressionistas ou os cadáveres queimados em grandes fornalhas nos campos de extermínio advêm desse plano de limpeza executado rigorosamente. São mero exercício da morte em escala industrial e burocrática.

Essa situação é vista por Jean-Luc Nancy e Philippe Lacoue-Labarthe, em $O$ mito nazista, como resultante de uma lacuna alemã há muito não-preenchida: a falta de identidade crônica. Citando Edgar Morin, os autores lembram que "do mesmo modo que o homem não se alimenta apenas de pão, uma sociedade não se alimenta apenas de gestão. Ela se alimenta também de esperança, de mito, de sonho" (LABARTHE; NANCY, 2002, p. 11). Acompanhando esse raciocínio, podemos observar a ideologia nazista como uma resposta a tal problema, total e politicamente determinada ${ }^{3}$. O que buscavam era uma ideologia capaz de reciclar o modelo grego, único disponível para a tradição alemã, grande leitora da língua helênica e fortemente influenciada por seu pensamento. A grande proposta de Hitler, nesse sentido, foi a de cicatrizar uma ferida aberta, oferecendo a possibilidade de um passado e de um futuro gloriosos. Pessoalmente responsável pela elaboração da insígnia nazista, bem como da bandeira, do estandarte e até do uniforme dos soldados, o Führer deu vazão a um projeto pseudo-artístico que fazia uso tanto do cinema e da escrita, quanto de desfiles e manifestações públicas, com comícios descomunais, em que ele próprio era enaltecido como o grande diretor, cenógrafo e protagonista. Encenando o mito do "corpo do povo", fundia-se a imagem de um único grito, uma única voz, na circulação a pulsar das multidões em praça pública.

Ora, se a representação é uma chave de leitura possível para a compreenssão da grandiosidade do projeto nazista, serve igualmente para pensar nos destroços por ele deixados, principalmente porque o discurso das vítimas fazia parte daquilo que os nazistas queriam eliminar. Diante das poucas representações que restaram, merece atenção o fato de ética e estética, caminhos distantes na representação nazista, cruzarem-se no trabalho de narrar a Shoah. Tentar distinguir entre os discursos das vítimas os relatos verdadeiros e falsos 
não me pareceu a melhor saída porque, como assegura Jean Améry (2001), pode-se devotar uma vida inteira a comparar o imaginário e o real e não chegar a nada com isso. Pensando, contudo, na transmissão da experiência do horror, é notável como a tarefa de comunicá-lo está limitada por diversos fatores, mas alguma aproximação permanece possível.

Obras como as de Primo Levi e Alain Resnais merecem destaque nesse cenário. São fundamentais para uma efetiva representação da Shoah. Muito embora Levi seja considerado um dos maiores escritores italianos do século XX, sua obra é pouco conhecida no Brasil. Muito além do estilo, seu texto tem a favor a capacidade de comunicar algo: não o julgamento dos malfeitores, mas o seu testemunho da própria incapacidade de testemunhar, tentando compreender o vivido através do detalhe, seja no olhar enigmático do carrasco, seja no sistema de leis tácitas estabelecido na zona cinzenta, sem no entanto conseguir fazê-lo. Compondo minuciosos painéis humanos e clamando para que se pense nas pessoas inseridas nesse microcosmo brutal, Levi alerta para que se evite a repetição do pesadelo, em qualquer lugar, sob quaisquer pretextos. Se o escritor demonstra a lacuna do muçulmano, personagem sem voz, homem irrepresentável e, nesse sentido, o mais importante e o mais desconhecido do campo, Resnais chama a atenção para as lacunas do tempo, a história que se liquefaz e consome o passado, encobrindo de verde relva o horror daquela terra nua. Representar a morte alheia equivale a dar testemunho de algo que lhes escapa, no espaço e no tempo. O que resta de Auschwitz pode ser lido apenas nas entrelinhas, entre mortos e vivos, afogados e sobreviventes.

Sobre Resnais, gostaria de lembrar ainda as palavras de um importante crítico de cinema, o norte-americano Jonathan Rosenbaum, que declarou em entrevistas que Noite $e$ neblina faz A Lista de Schindler parecer desenho animado. Se tal efeito de sentido é alcançado, deve-se ao rigor do projeto e ao comprometimento das partes envolvidas em sua produção, mas também à sensibilidade de quem soube fazer escolhas adequadas, contrastantes e aterrorizantes, não apenas porque aconteceram, mas também porque deixam claro sua atualidade: ainda podem vir a ocorrer novamente. A tônica das duas obras deixa no ar um aviso cujo alarme a soar, infelizmente, nos parece cada vez mais inaudível. Adorno defendeu com toda sua retórica - no bom sentido do termo - a impossibilidade da razão e da linguagem, o logos, permanecerem intactos após a experiência de Auschwitz. A aniquilação dos corpos humanos na dimensão em que se deu contaminaria a dimensão espiritual e intelectual, com conseqüências drásticas para a produção artística. Como sintetiza Jeanne Marie Gagnebin, criar após Auschwitz implica um movimento impossível, uma vez que deveria rememorar os mortos e, ao mesmo tempo, presenciar o sofrimento sem palavras nem conceitos, que desarticula a vontade de coerência e de sentido de nossos empreendimentos artísticos e reflexivos (GAGNEBIN, 2006, p. 79). Quer dizer, o ideal maior seria o de lutar contra o esquecimento e o recalque sem transformar a lembrança do horror em mais um produto cultural a ser consumido.

Devido à necessidade absoluta do testemunho superar, simultaneamente, sua impossibilidade lingüística e narrativa, o esforço paradoxal exigido por Adorno vem tomando, na atualidade, o caminho oposto, o da simplificação, do consumo e do esquecimento. A sensação que se tem é a de que tudo cai no vazio, na negação, na distância, no não. Vítimas do virtual, estamos como a mosca da metáfora de Baudrillard, a se chocar contra o vidro sem imaginar o que põe fim ao seu espaço. Conforme postula o pensador francês, o desenrolar da história foi desintegrado com a entrada em cena da informação, de modo que nos prendemos a um "tempo real" e negamos o que não se verifica nele. $\mathrm{O}$ virtual elimina não apenas a realidade, mas também a imaginação do real, do político, do social. Não somente a realidade do tempo, mas a imaginação do passado e do futuro: "a excessiva proximidade do acontecimento e de sua difusão em tempo real [pela mídia] cria a indemonstrabilidade, a virtualidade do acontecimento que lhe retira a dimensão histórica e o 
subtrai à memória" (BAUDRILLARD, 2005, p. 129). Isso justificaria tantas pessoas, os chamados negacionistas, afirmarem que os campos de concentração não existiram. A proposição de negação é absurda em si, como enfatiza o próprio Baudrillard. A questão central é então a de saber por que há necessidade de defender a verdade contra eles e por que a existência de câmaras de gás pode ser questionada.

Para a geração virtual, os fatos só existem no tempo em que eles próprios existem, depois se tornam passado, cadáver desaparecido, fantasma a vagar, cuja presença pode ser atestada apenas através de vestígios, por uma ausência que atesta uma presença, mas cuja presença pode ser também fictícia. O exemplo derradeiro de Baudrillard é exatamente o campo de extermínio, justamente por se situar no prolongamento do maior acontecimento assustador e ininteligível de nossa história moderna. Em suas palavras, o tempo real é um gênero de buraco negro onde nada penetra sem ser esvaziado:

de fato, os campos de exterminação tornam-se aí virtuais e só figuram na tela do virtual: todos os testemunhos, e o Holocausto e a Shoah, caem, apesar deles, apesar de nós, no mesmo abismo virtual - o de acontecimentos ou de fatos que existem no tempo que existem, ponto, nada mais (ibid., p. 58- 59).

Esgotando o horror na atualidade da imagem, os próprios testemunhos e os filmes, na sua sinceridade absoluta, não contribuiriam para essa memória impossível: a exterminação real está fadada a essa outra exterminação, a do virtual. Eis a verdadeira solução. Portanto, a proposição negacionista não pode ser realmente desmentida dado que tudo e todos nós, inclusive os que a recusam, inclinaram-se, voluntariamente ou forçados, para um tempo no qual não dispomos como outrora de recursos objetivos; estamos condenados, portanto, a resistir a isso numa espécie de refutação especular. Não se trataria da derrota do pensamento histórico e crítico, mas sim da vitória do tempo real sobre o presente, sobre o passado, sobre toda e qualquer forma de articulação lógica da realidade. É dessa forma que campos de extermínio como o de Auschwitz, cuja área foi tombada como patrimônio histórico da humanidade, transformaram-se em atração turística, com itinerários pré-determinados e horário marcado para sensibilizar-se com a dor alheia. Ali, a Shoah precisa conviver com a vontade de guias e de visitantes de um evento representável, assimilável e consumível, mercadoria de sucesso para jornadas de verão.

Não há, não mais do que qualquer outra coisa, função linear exponencial da catástrofe, e a perspectiva de sua ocorrência continua aleatória. De fato, não poderemos vivenciar nunca o relatado, sobretudo em nosso tempo de virtualidades. Baudrillard chama isso "dupla exterminação", ao que enfatizo o tom de uma "negação final", frente a uma "solução final" já inalcançável, Talvez até mesmo para os próprios sobreviventes, que, sem compreender bem o significado da vivência no tempo, foram obrigados a conviver com a sombra de um evento que nunca acabou dentro de si. Se a única forma de relação redimida entre "sujeito" e "objeto" postulada por Adorno implica um conhecer que não seja sinônimo de dominar, mas de atingir, tocar, e ser atingido e tocado de volta, cabe a cada qual tatear o próprio caminho. E seguir na direção das representações de Levi e de Resnais já é um primeiro passo. Certamente tomar esse rumo não vai resolver ou apagar o passado. Também não irá atualizá-lo no presente, ou garantir sua adequada preservação para o futuro. Todavia, é um favor que fazemos a nós mesmos. Em última instância, é uma chance de aproximação diante da morte anônima, inumerável e sem sentido que não diz respeito apenas a um outro, distante, e sim a nossa própria humanidade. 


\footnotetext{
${ }^{1}$ Cunhado por Michel Foucault em 1974, o termo biopolítica diz respeito a uma forma de poder em ascensão silenciosa e contínua, responsável por fazer viver e deixar morrer. Para uma síntese histórica do termo, conferir: PELBART, Peter Pál. Vida capital: Ensaios de biopolítica. São Paulo: Iluminuras, 2003.

${ }^{2} \mathrm{O}$ ponto extremo dessa política é retratado no documentário Arquitetura da destruição [Architektur des Untergangs, 1989/1992], de Peter Cohen. Defendendo que "o maior princípio de saúde é a beleza", Hitler afirmava, já em 1935, que a ciência dispunha de métodos capazes de assegurar esse bem. Assim, artistas, médicos e cientistas incorporaram o ideal do guerreiro biológico que na luta pela higienização defende a destruição e o assassinato como melhor forma de construção e terapia. Em outras palavras, em prol de um ideal de beleza e harmonia acreditou-se necessária a destruição de tudo aquilo que fugisse a um padrão préestabelecido.

${ }^{3}$ Buscando uma compreensão acerca de alguns conceitos da Dialética do esclarecimento, principalmente os que dizem respeito às proposições de mito, mimesis e identidade em Theodor Adorno, Jeanne Marie Gagnebin oferece uma leitura de alguns pontos da polêmica obra de Lacoue-Labarthe e Nancy, evidenciando como a eficácia dos elementos miméticos nazistas era decorrente da capacidade identificatória de tais elementos. Cf. GAGNEBIN, J. M. “Após Auschwitz". In: Lembrar, escrever, esquecer. São Paulo: Ed. 34, 2006, p. 5981.
}

\section{REFERÊNCIAS}

ADORNO, Theodor W. Minima moralia: reflexões a partir da vida danificada. Trad. Luiz Eduardo de Oliveira Bicca. São Paulo: Ática, 1993.

. Crítica cultural e sociedade. In: . Prismas. Trad. Augustin Wernet e Jorge Mattos Brito de Almeida. São Paulo: Ática, 1998.

AGAMBEN, Giorgio. Homo Sacer III. Lo que queda de Auschwitz: el archivo y el testigo. Trad. Antonio Gimeno Cuspinera. Valencia: Pré-textos, 2000.

Homo Sacer: O poder soberano e a vida nua I. Trad. Henrique Burigo. Belo Horizonte: UFMG, 2004.

AMÉRY, Jean. Más allá de la culpa y la expiación: Tentativas de superación de una víctima de la violencia. Valencia: Pre-textos, 2001.

ARCHITEKTUR des Untergangs [Arquitetura da destruição]. Direção de Peter Cohen. Suécia: Versátil Home Vídeo, 1992. 1 filme (121 min): legendado, preto e branco / colorido.

ARISTÓTELES; HORÁCIO; LONGINO. A poética clássica. Trad. Jaime Bruna. 12 ed. São Paulo: Cultrix, 2005.

AUERBACH, Erich. Mimesis: A representação da realidade na literatura ocidental. Trad. Jayme Salomão. 4 ed. São Paulo: Pespectiva, 1998.

BAUDRILLARD, Jean. A troca impossivel. Trad. Cristina Lacerda e Teresa Dias. Rio de Janeiro: Nova Fronteira, 2002.

Tela Total: Mito-ironias do virtual e da imagem. Trad. Juremir Machado da Silva. Porto Alegre: Sulina, 2005. 
BENJAMIN, Walter. Obras Escolhidas I: Magia e técnica, arte e política. Trad. Sérgio Paulo Rouanet. São Paulo: Brasiliense, 2000.

FELMAN, Shoshana. Educação e crise, ou as vicisitudes do ensino. In: NESTROVSKI, Arthur; SELIGMANN-SILVA, Márcio (orgs.). Catástrofe e representação: ensaios. São Paulo: Escuta, 2000, p. 13-71.

FREUD, Sigmund. Além do Princípio do Prazer. Obras psicológicas completas de Sigmund Freud: edição standard brasileira. Vol. XVIII. Rio de Janeiro: Imago, 1980, p. 13-85.

GAGNEBIN, Jeanne Marie. Lembrar escrever esquecer. São Paulo: Ed. 34, 2006.

LABAKI, Amir. Noite e neblina. Disponível em: <http://www.etudoverdade.com.br/ periodico/coluna/coluna.asp?lng=\&id=224>. Acesso em 20 fev. 2008.

LABARTHE, Philippe Lacoue; NANCY, Jean-Luc. O mito nazista. Trad. Márcio SeligmannSilva. São Paulo: Iluminuras, 2002.

NANCY, Jean-Luc. La representación prohibida. Trad. Margarida Martínez. Buenos Aires: Amorrortu, 2006.

LEVI, Primo. É isto um homem? Trad. Luigi Del Re. São Paulo: Rocco, 1988.

Os afogados e os sobreviventes: os delitos, os castigos, as penas, as impunidades. Trad. Luiz Sérgio Henriques. São Paulo: Paz e Terra, 2004.

NESTROVSKI, Arthur; SELIGMANN-SILVA, Márcio (orgs.). Catástrofe e representação: ensaios. São Paulo: Escuta, 2000.

NOITE e neblina [Nuit et brouillard]. Direção de Alain Resnais. França: Dist. Aurora DVD, 1995. 1 filme (32 min): legendado, colorido / preto e branco.

PELBART, Peter Pàl. Ensaios de Biopolítica. In: - Vida Capital 2. São Paulo: Iluminuras, 2003.

RAMOS, Célia Maria Antonacci. As nazi-tatuagens: inscrições ou injúrias no corpo humano? São Paulo: Perspectiva, 2006. 